\title{
Government departments clash over US drilling proposals
}

\section{Berkeley}

THE Environmental Protection Agency (EPA) has joined a growing chorus opposing the Interior Department's plan to lease 1.1 million acres off northern California for oil and gas exploration.

Interior Secretary Donald Hodel proposes leasing more than 200 three-milesquare tracts as the first step of a five-year plan to develop northern Californian oil and gas. Optimistic estimates predict as much as 790 million barrels of oil. But

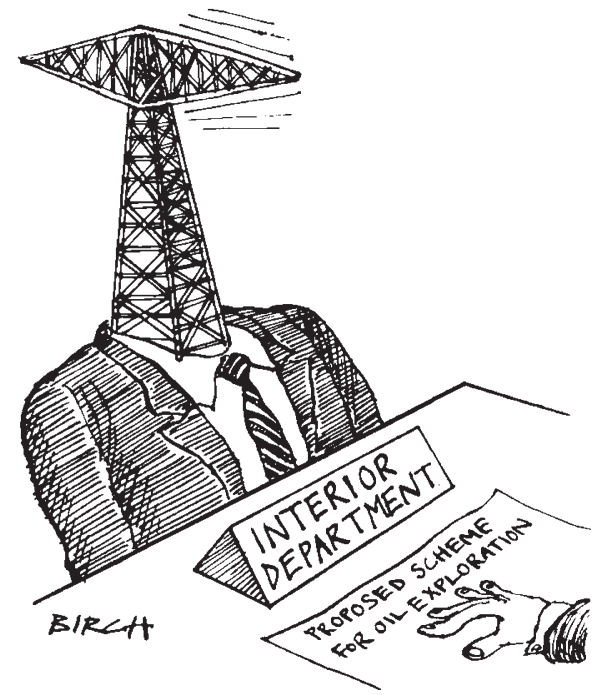

opponents of the plan like to point out that even such optimistic estimates would satisfy US demand for fuel for less than two months.

Supporters of the oil exploration, including the California Chamber of Commerce, argue that the state has a responsibility to allow development of resources off its coast.

The Interior Department issued a draft environmental impact statement last December, and is currently reviewing public comments on the statement. If it goes through with leasing, the tracts will be auctioned in February 1989.

In its response to the impact statement, EPA expressed concern for two national wildlife refuges, the Farallon Islands, about 30 miles off the Golden Gate, and Point Reyes, on the coast north of San Francisco. The refuges are important breeding grounds for 10 species of seabirds, including the common murre, a diving bird particularly sensitive to oil spills. The area is also of importance to fisheries, and supports many marine mammals, including migrating whales, says EPA spokeswoman Virginia Donohue.

EPA has asked the Interior Department to find leasing configurations more protective of the Farallons, Point Reyes and several river-mouth habitats.

\section{Spain lays down the law on research plans}

\section{Barcelona}

THE National Plan for Research (NPR) has finally been approved by the Spanish government. It represents the main attempt by the Socialist government to put into effect the Law of Science of 1985 and to concentrate the effort devoted to civil research. The plan covers the period 1988 91 and is intended to co-ordinate the programme of the various ministries involved in research, and to increase expenditure on research from 0.7 per cent of gross national product to 1.2 per cent by the end of 1991 . It is also proposed to increase by around 50 per cent the number of researchers, who now represent 0.12 per cent of the population.

The NPR requires the expenditure of more than 600,000 million pesetas $(£ 3,000$ million) in four years - though only a third of this represents actual funding of research in Spanish government and industrial laboratories. The budget also has to cover Spanish participation in international programmes and administrative expenses. The plan includes programmes aimed at encouraging high-quality basic research and at stimulating international co-operation.
But the most important element is a group of 23 programmes where efforts will be concentrated in defined areas. Production technology (microelectronics, robotics, new materials and so on) and telecommunications account for half the total spending. The 'natural resources and agrobiology' programmes include food technology, agriculture and geological resources; it also includes a programme of Antarctic studies as a continuation of a recent expedition on which for the first time a Spanish base was occupied during the Antarctic summer. Another important programme is biotechnology, in which most of the funding will go to the new Centre for Biotechnology in Madrid. In the opinion of the secretary general of the NPR, Dr Emilio Muñoz, the plan provides insufficient funds for social and human sciences and for health research, but annual revisions of the plan will make it possible better to define and finance the weakest areas. Another imponderable is the response of private industry. Few Spanish companies have so far shown an interest in adopting new technologies, and unless things change, both the results of the research and the trained personnel may be wasted.
The EPA recommendations are not binding, but as a federal agency, EPA expects to be taken seriously. Its comment is one of 5,000 the Interior Department has received from federal and state agencies, environmental groups, industry and thousands of individuals. Drilling opponents have also packed the house at several volatile hearings on the plan. Although it seems likely that oil development will proceed, the department may be forced to modify its plan in response to the public comments.

Marcia Barinaga

\section{Universal health insurance in Massachusetts}

\section{Boston}

A landmark bill passed into law last week makes Massachusetts the first state in the United States to provide a universal health insurance plan. Under the scheme, employers, workers and state taxpayers will gradually assume financial responsibility for health care for uninsured Massachusetts residents.

The bill, which received narrow approval in the state senate after a marathon 12-hour debate and a tumultuous nine-month legislative history, seeks to provide health care coverage for the 600,000 of the state's 5.8 million residents who are currently uninsured. Half the potential beneficiaries are also unemployed.

Under the act, companies with more than five employees must pay a yearly surcharge of roughly $\$ 1,680$ per worker which will go to a new health insurance fund. If, however, these companies offer health insurance benefits to their workers, they will be allowed to deduct the cost of insurance from the surcharge. Small businesses with fewer than five employees are exempt. Starting in 1992, the new law will allow uninsured residents to pay for their own insurance on a sliding scale based on how much they earn.

Michael S. Dukakis, Massachusetts governor and the current leader in the race to be the Democratic candidate for president, was a strong supporter of the bill and made it a prominent topic in his presidential bid. Massachusetts Republicans complained that the bill had been pushed through the state legislature especially quickly in order to influence the presidential campaign.

But the measure has generated widespread support in Massachusetts, and other state legislatures will be watching its implementation closely. The bill is expected to cost the state approximately $\$ 1,000$ million over the next four years, and to generate roughly the same amount in additional revenues to the local hospital industry.

Seth Shulman 